\title{
A lake's life is not its own
}

George W. Kling

Little is known about how lakes change as they get older. Research on a

12,000-year sequence of natural laboratories at Glacier Bay, Alaska, shows how the terrestrial surroundings can influence lake evolution.

magine a landscape suddenly released from the frozen grip of a kilometre-thick glacier. Bare rock crumbles to pockets of dust that harbour sprouting seeds, and soon patches of plant species adapted to this environment appear. As the environment gradually changes, the ensuing development of the flora - a process known as succession proceeds roughly in step with predictions from theories of plant community dynamics. As ecology goes, we have a good idea of what happens in these circumstances.

But what of the numerous lakes left in depressions after the glacier has retreated? Surely science can also predict their development? Well... no. Unlike terrestrial ecology, which is founded in part on numerous studies of plant succession, aquatic ecologists have only the sketchiest of ideas about succession in lakes; there is no workable theory of how their chemistry and biology evolve. On page 161 of this issue ${ }^{1}$, Engstrom et al. present a powerful data set that provides insights into what happens in the first few years of a lake's life - and also the following thousands of years. More importantly, they can give reasons why the lakes they studied evolved as they did.

Why aren't there any general theories of lake development? One of the original ideas from the founder of this field, the late Ed Deevey at Yale University, was that lakes become more productive as they age; that is, the amount of biomass created in the lake increases. Although that is sometimes true, and the notion is often taken as accepted fact, it has long since been evident that it simply

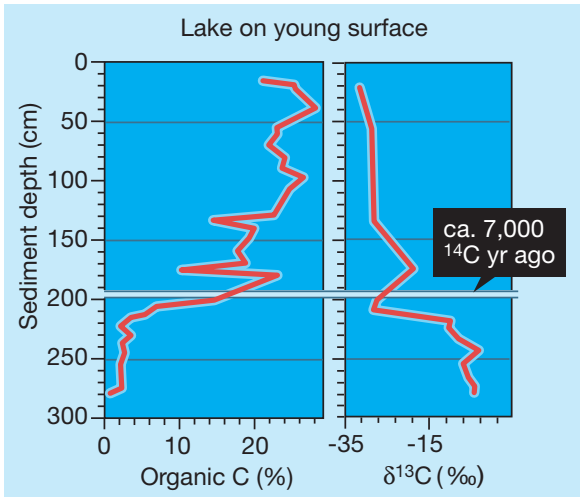

fails to hold as a generality ${ }^{2}$. There are also studies of how lakes develop towards the end of their existence, such as Walker's ${ }^{3}$ classic analysis from the British Isles of how lakes become land. But the variable patterns of succession from open water to swamps, and from bogs to forest, were predictable only in the coarsest statistical sense.

Perhaps the big problem is that the chance of observing lake evolution is so rare. Yes, there are hundreds of artificial reservoirs that we could track through history, but most of them flush so freely that they never truly develop as lakes, surviving instead as wide, slowly flowing rivers. And the approach of comparing lakes formed at different times is difficult, because most lakes were formed at the end of the last glaciation, at least 10,000 years ago. That makes the gap between recent reservoirs and natural lakes too great, and interpolation between those two points forms an uninteresting line.

Enter Engstrom et al. ${ }^{1}$, who have taken advantage of a natural experiment - the advance and final retreat of ice at Glacier Bay, Alaska, over the past 12,000 years. The end result is a superb sequence of natural laboratories in the form of lakes ranging from 10 years to 12,000 years in age (see the map on page 162 of the paper). The authors looked first across all the lakes for patterns in diatom species (lake algae) and water chemistry that were related to the age of the lake. They next studied the history of each lake, as recorded in the form of fossil diatoms and the chemistry of sediments buried over time. The patterns they found in the results of these

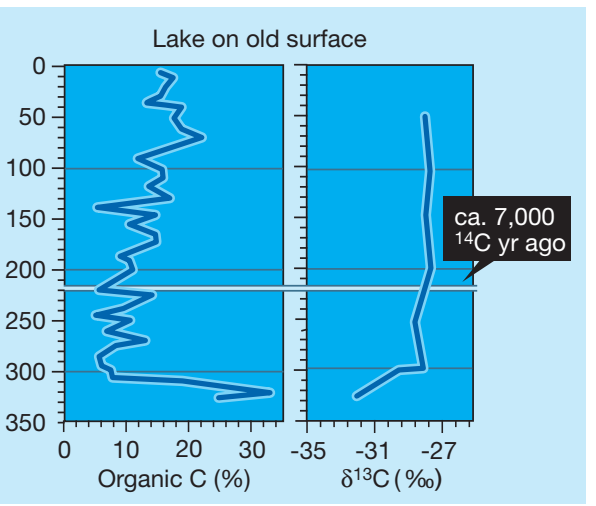

Figure 1 Variation of organic-carbon content and $\delta^{13} \mathrm{C}$ value in the sediments of two lakes in arctic Alaska $^{5}$. Both lakes experienced the same climatic transition about 7,000 years ago. But the carbon chemistry (an indicator of processes happening in the catchment area or the lake itself) responded only in the lake on the young surface. This example shows how landscape characteristics can override the effects on lake development from even rapid and strong climate change. comparative and historical approaches match, which is wonderful as it adds great confidence to the group's conclusions.

Engstrom and colleagues show that their lakes have become more dilute, more acid and more coloured with dissolved organic matter over time (and, by inference, less rather than more productive). The authors' explanations are intricate but don't hide the main picture that the terrestrial surroundings have controlled lake evolution. But this control is not as simple as the depletion of easily weathered minerals in the catchment area causing the runoff waters to become progressively more dilute. Rather, there appears to be a 200-year lag in the initial changes in lake chemistry and biology, a lag which coincides with the development of soils and vegetation in the Glacier Bay area. Such soil development eventually excludes water from running through the deeper, mineral-rich substrates and into the lakes. Even the details of variation between individual lakes in Engstrom and colleagues' study can be explained by the geomorphological control of local hydrology.

These results ${ }^{1}$ will help to reshape our understanding of lake evolution. The eventual goal is to predict how aquatic ecosystems respond to the interaction of landscape geomorphology, climate change and ecological factors acting through terrestrial vegetation or within the lake itself. This is the real mystery story, with the potential factors and mechanisms being so intertwined that it seems hard to isolate a problem let alone an answer.

Yet there is hope. We now have Engstrom and colleagues' evidence that geomorphological controls can dominate lake development in some cases. And Birks et al. ${ }^{4}$ have shown that sudden variations in aquatic ecosystems resulted from rapid climate change (during the last glacial-to-interglacial transition, about 14,000 years ago), while longerterm variation since then resulted from the interplay of climate and changes in the catchment area and in the lakes themselves.

In a further twist ${ }^{5}$, it seems that a lake's response to a strong shift in climate may be overridden by geomorphological controls. For example, arctic Alaska experienced a regional change in climate about 7,000 years ago $^{6}$. This resulted in dramatic alterations in the carbon chemistry of sediments in a lake on a young, topographically varied landscape, but little or no stratigraphic variation in a neighbouring lake on a much older, smoother landscape (Fig. 1). The two lakes were exposed to identical climates and are similar in nature. Yet these indicators of carbon inputs or lake metabolism varied greatly across the climate transition in only one of the lakes.

In revising our ideas about lake development, it is clear that climate, geomorphology and ecology are all major players that can smother each other now and then. We must discover patterns of when and where this has 
happened in the past, as these will guide our thinking about how aquatic ecosystems will change in the future. This great paper ${ }^{1}$ pushes us along, and it'll be fun to see how it all works out.

George W. Kling is in the Department of Biology, University of Michigan, Ann Arbor, Michigan 48109-1048, USA.

e-mail: gwk@umich.edu

1. Engstrom, D. R., Fritz, S. C., Almendinger, J. E. \& Juggins, S. Nature 408, 161-166 (2000)

RNA silencing

\title{
Moving targets
}

\author{
James C. Carrington
}

Viruses have evolved several strategies to attack plants, but the plants keep hitting back. So the viruses have upped the ante by stopping the plants' immune response from spreading to uninfected tissues.

D) lants have developed a variety of weapons in their battle against viral invaders, one of the most elegant of which is 'RNA silencing'. The beauty of this immune response lies in its ability to adapt to all sorts of different viruses, because its specificity is dictated by the sequence of the viral genome itself. Another clever feature is that a signal that triggers silencing is not restricted to individual plant cells, but can spread from the site of infection, generating a response in more distant tissues. But it seems that viruses do not admit defeat easily. Both viruses and these plant-wide ('systemic') silencing signals spread from cell to cell through channels that traverse the cell walls. The spread of the viruses is dependent on viral 'movement proteins'. Writing in Cell', Voinnet and colleagues show that these movement proteins may also debilitate the systemic arm of the silencing response.

RNA silencing can be triggered in plants by replicating viruses, double-stranded RNA molecules and foreign genes (transgenes) that allow the production of high levels of normal or aberrant messenger RNAs ${ }^{2}$. Silencing induced in this way by viruses limits the accumulation of the inducing virus, and can also confer immunity in the plant against closely related viruses.

The best model for how RNA silencing works ${ }^{3}$ suggests that double-stranded segments within an RNA target, such as a viral RNA, are recognized by a plant RNAdigesting enzyme (a 'dsRNase') that contains regions for binding to and untwisting doublestranded RNA. This nuclease cleaves the target RNA to produce segments 21-23 nucleotides in length. These small RNAs associate with the dsRNase or another RNAdegrading nuclease, and confer specificity in further RNA-degradation reactions because they can pair up with complementary singlestranded target RNA.

2. Livingstone, D. A. Am. J. Sci. 255, 364-373 (1957).

3. Walker, D. in Studies in the Vegetational History of the British Isles (eds Walker, D. \& West, R. G.) 117-139 (Cambridge Univ. Press, 1970). 91-114 (2000)

5. Hu, F. S., Oswald, W. W., Brubaker, L. B. \& Kling, G. W. in Geomorphic and Climatic Controls over Holocene Soil Development on the Arctic Foothills of Alaska 204 (Ecol. Soc. Am. 85th Annual Meeting, 6-10 August; Snowbird, Utah, 2000)

6. Brubaker, L. B., Anderson, P. M. \& Hu, F. S. in Arctic and Alpine Biodiversity (eds Chapin, F. S. \& Korner, C.) 111-125 (Springer, Berlin, 1995).
4. Birks, H. H., Batterbee, R. W. \& Birks, H. J. J. Paleolimnol. 23 ,
Viral genomes come in DNA or RNA strong inducers of RNA silencing because double-stranded RNA is formed, at least temporarily, during replication of the genome. The silencing mechanism may halt the replication of the virus in the infected area. Moreover, plant tissues far from the infected site also show specificity in silencing the viral RNAs ${ }^{4}$. The most plausible explanation for this is that a mobile signal - containing nucleic acids corresponding to the RNA target - spreads from cell to cell.

One strategy that viruses deploy to overforms; viruses with RNA genomes may be

come the silencing response is to move rapidly throughout the plant before silencing can shut them down. Such systemic spread of the virus requires virus-encoded movement proteins. These come in a variety of forms ${ }^{5}$ : some are enzymes, while others have structural roles. Some of them localize to plasmodesmata (the channels connecting plant cells), affect the ability of these channels to open and close, and stimulate transport of themselves and nucleic acids (the viral genome) to the neighbouring cell. In many cases, the functions of the movement protein are split among several proteins. For example, the RNA virus potato virus $\mathrm{X}$ (PVX) has three movement proteins - p25, $\mathrm{p} 12$ and $\mathrm{p} 8$. The conventional view is that these proteins coordinate the movement of the virus to plasmodesmata, the alteration of the channels to accommodate the virus, and transit of the virus through the channels.

This model has merit but - given the finding by Voinnet et al. ${ }^{1}$ that p25 is a suppressor of systemic RNA silencing - it may be too limited. The 25 protein is not the first silencing suppressor in a plant virus to be identified ${ }^{6-8}$. But the fact that it is also a movement protein indicates that viral movement might depend both on interactions between movement proteins and plasmodesmata, and on suppression of the plant's silencing mechanism.

Two of Voinnet et al.'s results ${ }^{1}$ are worth mentioning in more detail here. First, p25 specifically inhibits the production of the systemic silencing signal. This was shown using plants engineered to express a transgene

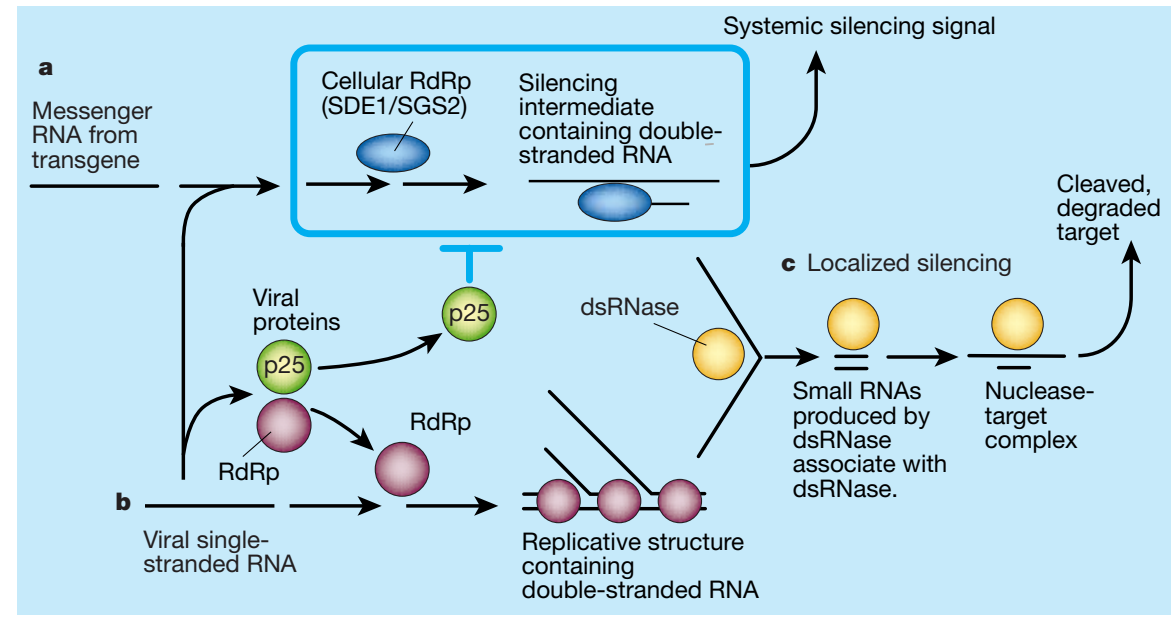

Figure 1 Plants may have a two-pronged strategy for silencing viruses, as suggested by Voinnet et al. ${ }^{1}$. a, The 'weak-inducer' branch. RNAs with limited double-stranded structure - such as those encoded by foreign genes (transgenes) or resulting from replication of a viral genome - feed into this pathway. Silencing depends on a cellular RNA-dependent RNA polymerase (RdRP)-like protein (such as SDE1/SGS2). SDE1/SGS2 produces double-stranded RNA using the single-stranded RNA as a template. This branch also results in the production of a systemic silencing signal and is inhibited by a movement protein, p25, from the potato virus X. b, The 'strong-inducer' branch. Replication of the genome of an RNA virus, using a viral RdRp, produces some replication intermediates with doublestranded-RNA structure. This pathway is not inhibited by p25 and does not lead to systemic silencing. c, Both pathways lead to localized silencing. A 'dsRNase' enzyme cuts up the doublestranded RNAs. The resulting small RNAs associate with the dsRNase or another RNA-degrading nuclease, which cleaves target RNAs that pair up with the small RNAs. 